\title{
Back to War in Mindanao: \\ The Weaknesses of a Power-based \\ Approach in Conflict Resolution
}

\author{
By Nathan Gilbert Quimpo
}

(To be published in the Philippine Political Science Journal, vol. 21, no. 44, 2000.)

In October 1999, amid a bit of pomp and pageantry, negotiating panels of the Government of the Republic of the Philippines (GRP) and the separatist Moro Islamic Liberation Front (MILF) opened “formal peace talks” at the Da'wah Center in Sultan Kudarat, Maguindanao, only about ten kilometers away from the MILF’s headquarters, Camp Abubakar. Among those who graced the occasion were Defense Secretary Orlando Mercado, Presidential Adviser on Flagship Projects Robert Aventajado, Presidential Adviser on the Peace Process Manuel Yan, MILF Vice-chairman for Political Affairs Ghazali Jaafar, MILF Vice-chairman for Internal Affairs Aleem Abdul Aziz Mimbantas and MILF Vice-chairman for Information Mohagher Iqbal, and a number of representatives from the diplomatic community. The two sides had actually been engaged in peace negotiations since 1996, just a few weeks before the signing of the September 1996 peace agreement between the government and the Moro National Liberation Front (MNLF), but these had been regarded as merely “exploratory” and "informal” in nature. One of the results of this exploratory talks had been an agreement for general cessation of hostilities, signed in July 1997. Despite the ceasefire agreement, armed hostilities between government and MILF forces broke out time and again. Somehow, up until 
the formal talks, the ceasefire always managed to be restored. The scale of fighting, however, appeared to be getting bigger each time.

In February 2000, less than four months after the opening of the formal talks, serious fighting erupted for the nth time but this one escalated in a few weeks into the most serious in over a decade. President Joseph Estrada declared an "all-out war" against the MILF and vowed to dismantle its camps. Amid all the shooting, negotiators of the two sides continued to meet, but the talks were doomed. In early July, Camp Abubakar, the last of the MILF camps, fell into government hands. Soon after, MILF chairman Salamat Hashim called on the Moro people rise in jihad (struggle in the cause of Allah) against the "enemy of Islam”.

“This long and useless war is finally over,” Defense Secretary Mercado is quoted to have said soon after entering the freshly-captured Camp Abubakar. ${ }^{i}$ In the week that followed, Mindanao was rocked by several violent incidents - two MILF ambushes, an armed encounter between government and rebel forces, a bombing in a public market and a massacre of 21 residents of a small farming village. In the wake of these, Mercado denied having said that the war was over and conceded that the MILF rebels remained capable of hitting government forces even though they had lost all their camps. ${ }^{\text {ii }}$ Indeed, despite the grave reverses suffered by the MILF, most political and military analysts believe that the rebel group is far from being an annihilated or spent force. The MILF's main combat units are, in fact, believed to be still largely in tact, having judiciously avoided a strategic confrontation with superior government forces during the latter’s recent offensives. With the MILF now girding for a protracted guerrilla war, the prospects of attaining peace in the near future appear to be dimming.

Why did the GRP-MILF peace talks collapse? It can be facilely said, of course, that the government's “all-out war” against the Moro rebels caused the talks to break down. But then, why did the government opt for war again instead of persisting with ceasefire-and-negotiations? 


\section{Approaches in Dispute Resolution}

To analyze why the talks collapsed and why the government and the MILF are again on the warpath, I will delve into the approach in dispute resolution that the two parties employed, paying particular attention to the past four years of negotiations, on-off ceasefire and armed combat. As the MILF is a rebel force that broke away from the MNLF and the MILF struggle is part of the larger "Bangsamoro struggle”, I will first discuss at some length the approach in dispute resolution in the older GRP-MNLF conflict. The main thesis of this paper is that the collapse of the GRP-MILF peace talks can be traced to the weaknesses of a power-based approach in resolving the dispute between the government and the Moro rebels in general.

Before I proceed to discuss my main point, let me first briefly present the different approaches that have been used in resolving international as well as civil disputes or conflicts.

Scholars in the field of conflict and peace studies have identified three general approaches to resolving disputes or conflicts, namely: 1) a power-based approach; 2) a rights-based approach; and 3) an interest-based approach. Connie Peck briefly describes these three approaches as follows:

In the first approach [power-based approach], disputing parties attempt to determine who is most powerful through a power contest. In international relations, war is the most obvious and extreme version of this approach, but less intense forms are also common. In a rights-based approach, the parties try to determine who is right according to some standard. International law is the standard most commonly used. Arguments and evidence are presented to prove that the other was in breach of some agreed-upon rule, such as a treaty, convention or accepted custom. In an interest-based approach, parties attempt to reconcile their underlying 
interests by discovering solutions which will bridge their different needs, aspirations, fears or concerns in a manner that is satisfactory to both.

The three approaches, however, are often related. As Ury and his colleagues state: “The reconciliation of interests takes place within the context of the parties' rights and power ... Thus, in the process of resolving a dispute, the focus may shift from interests to rights to power and back again” (Ury et al., 1988, p. 9). ${ }^{\text {iii }}$

Traditional negotiation and mediation often make use of a power-based approach. In traditional negotiation, contending sides engage in "hard bargaining” with each side adopting and justifying hard-line positions and trying to convince the other to make concessions through various tactics and ploys. Negotiation becomes like a chess game, as each side tries to "outmaneuver" and "outsmart" the other. A third party mediator, when involved, tries to help the contending parties understand one another's position, make concessions and eventually reach a compromise. "In the process of traditional negotiation or mediation,” writes Peck, “negotiators or mediators may be aware of some of the parties’ interests, but they are not systematically explored and they are seldom the focus of the negotiations. Instead, the parties' positions (preferred solutions) define the process." iv

\section{GRP-MNLF Power Contest: The Battle Front and the Politico-Diplomatic Front}

The historical roots of the armed conflict in Mindanao can be traced back to the Spanish and American colonial periods when indigenous Muslim tribes resisted against subjugation and being driven away from their lands. In terms of more immediate causes, however, the present armed conflict in Mindanao dates back to the late 1960s and early 1970s when disputes over land between Christian settlers and Muslim farmers increasingly turned violent and paramilitary groups formed by Christian landlords and loggers and by Muslim politicians 
conducted raids and attacks against each other and on Muslim and Christian civilian populations. With an increasing number of Muslims perceiving the government as being on the side of "Christian landgrabbers", the "Christian-Muslim” conflict escalated into a full-blown war after President Ferdinand Marcos imposed martial law in September 1972. The MNLF, established in 1969 by young Muslim radicals led by former University of the Philippines professor Nur Misuari, emerged as the rallying symbol and leading force of the Moro rebellion. Charging the government of waging a systematic campaign of genocide against the Moro people, the MNLF called for the secession of Mindanao ${ }^{\mathrm{v}}$ and the establishment of an independent Moro state.

The government and the MNLF employed a power-based approach in the resolution of their conflict. In the first few years, the GRP-MNLF power contest was mainly played out in the battlefield. It was during this period that the Mindanao war was fought most ferociously, claiming tens of thousands of casualties and forcing hundreds of thousands to flee from their homes. The MNLF mobilized enormous financial and material support (including arms) from various Muslim countries, movements and organizations. Its chief backer was the Libyan leader Muammar Khadaffy, who poured millions of British pounds to arm the rebels and provided them military training as well. ${ }^{\mathrm{vi}}$

In subsequent years, the armed conflict continued - on and off - but the main arena of the power contest actually shifted elsewhere. For the most part of a quarter of a century of conflict, the GRP-MNLF power contest was mainly fought out not in the battlefield but in the politico-diplomatic arena. It was the MNLF, the much weaker force, that sought to bring the conflict into this arena. The Moro rebel group, already enjoying substantial financial and material support from Muslim countries, endeavored to further "internationalize” the conflict by campaigning for their political support as well, including diplomatic recognition of its self-proclaimed "Bangsamoro Republik". vii The MNLF focused its attention on the 
Organization of the Islamic Conference (OIC), the international association of Muslim states, which had already expressed "serious concern for the plight of the Filipino Muslims” in 1972, viii and had been closely monitoring developments in Mindanao since then.

The MNLF's efforts soon paid off but the results were not exactly to its full liking. In 1974, the OIC passed a resolution calling on the Philippine government to find a political and peaceful solution through negotiation with the MNLF. ${ }^{\text {ix }}$ By being officially mentioned in the resolution, the MNLF made a diplomatic breakthrough: recognition by an important international governmental organization. On the other hand, however, the OIC, some of whose member countries were beset with secessionist problems of their own, rejected the MNLF's secession bid. The OIC urged the two disputing sides to arrive at a just solution to the Mindanao problem "within the framework of the national sovereignty and territorial integrity of the Philippines". ${ }^{x}$

The war reached a virtual stalemate. The Philippine economy reeled from the costs and effects of the war and from an oil embargo imposed by the Organization of Petroleum Exporting Countries (OPEC) on pro-Israel countries in 1973. To get the oil embargo on the Philippines lifted, the government had to smoothen ties with Muslim oil exporting countries and take extra care not to antagonize them. Marcos acceded to peace talks under OIC mediation - yet another diplomatic win for the MNLF.

\section{Peace Talks - A Continuation of the Power Struggle by Other Means}

The peace negotiations did not end the power contest between the government and the MNLF, but in fact, became part of it, or as Peck would have put it, "a continuation of the power struggle by other means." xi During the negotiations, the two sides engaged in a politico-diplomatic struggle and on-off military struggle, each side engaging in tactics and 
ploys, maneuvers and counter-maneuvers, as in a chess game, to compel the other side to give in to the other's demands or make concessions.

Flushed with its initial successes at the OIC, the MNLF persisted with its efforts to gain diplomatic support for its secession bid. Marcos, however, countered with a politico-diplomatic offensive of his own. He dispatched delegations (including his wife Imelda as special emissary) to key Arab countries, opened more embassies in the Middle East and North Africa and strengthened ties with Muslim countries. In Mindanao, taking advantage of local ceasefires, Marcos succeeded in luring a number of MNLF commanders to surrender through a "policy of attraction” with offers of amnesty, livelihood projects and political positions. $^{\text {xii }}$

Sticking to its "no secession” position, the OIC supported regional autonomy as the basis for GRP-MNLF negotiations. It pressed the MNLF to accept autonomy. After intense debate within its ranks, the MNLF relented, out of fear of being isolated from their Muslim brothers. ${ }^{\text {xiii }}$

In December 1976, the government and the MNLF, with the OIC as mediator, signed the Tripoli Agreement, which provided for the establishment of an autonomous region consisting of thirteen provinces (including all the cities therein) in southern Philippines. In general terms, the agreement laid out the autonomous region's administrative system, executive and legislative bodies, and representation in the national government; special regional security forces; educational system; economic and financial system; exploitation of mines and mineral resources; and shari'ah courts and judiciary.

The Tripoli Agreement, as it turned out, was not an instrument of true peace, but just another pawn in the GRP-MNLF power play. In a clever last-minute maneuver, Marcos, through the Philippine government’s chief negotiator, Defense Undersecretary Carmelo Barbero, had succeeded in backroom negotiations in getting the provision that "the Philippine 
government shall take all necessary constitutional processes for the implementation of the entire Agreement” inserted in the accord's final text. ${ }^{\text {xiv }}$ Following the signing of the agreement, the MNLF expected an autonomous region of thirteen provinces to be immediately established. In talks on the implementation of the agreement, however, the Marcos government insisted that as part of the "necessary constitutional processes", a plebiscite first had to be held to determine if the people in the thirteen provinces were amenable to being part of the autonomous region. Despite MNLF objections, Marcos went ahead with the plebiscite and subsequently, with his own version of autonomy, creating two autonomous regions - not just one - out of the ten provinces that voted for autonomy. The talks collapsed.

\section{Post-Tripoli Agreement: Power- and Rights-Based Approaches}

After the signing of the Tripoli Agreement, the Philippine government, the MNLF and the OIC mainly continued with a power-based approach in conflict resolution and mediation, but they combined it this time with a rights-based approach. In the latter approach, the two contending parties and the third party mediator often referred to a common standard - the Tripoli Agreement - to point out which party was right and which party was wrong, i.e., which party was abiding by the standard and which party was in breach of it.

Reacting angrily to Marcos’ maneuvers in “implementing” the Tripoli Agreement, the OIC held the Philippine government responsible for the failure of the negotiations and accused it of "shirking its international responsibilities". The OIC granted the MNLF observer status in the organization, recognizing it as the "legitimate representative of the Muslim Movement in South Philippines”. ${ }^{\mathrm{xv}}$ In gaining OIC observership, just one notch below full member status, the MNLF achieved a major diplomatic feat. Now it was being treated at near parity with Muslim states. 
Just before its feat at the OIC, however, the MNLF had suffered a major blow - a split in its ranks. The split broke out into the open towards the end of 1977. Charging Misuari with corruption, authoritarianism and replacing Islam with Marxist-Maoist ideology, a group led by MNLF vice-chairman Hashim Salamat broke away and formed the "new MNLF" (which in 1984 became the MILF). The MNLF under Misuari reverted to its original goal of secession; Salamat's group pushed for the implementation of the Tripoli Agreement. In 1982, the MNLF experienced another split, with Dimasangkay Pundato forming the "MNLF Reformist Group”. Although the leaders of the three MNLF fractions tried to downplay ethnic differences and rivalry, these were an important factor in the split, each leader drawing support mainly from his own ethnic group: Misuari from the Tausugs; Salamat, Maguindanaos; and Pundato, Maranaos. With the three-way split, the MNLF never again regained the military strength that it had attained in the early years of martial law.

Much weakened in the battlefront, Misuari’s MNLF proved that it could still sustain the power contest against the Marcos government in the politico-diplomatic front. It maintained its observer status in the OIC, which decided in 1978 to continue recognizing Misuari as MNLF chairman and spokesman. The following year, the MNLF gained a new supporter, the newly-installed government of Ayatollah Khomeini in Iran, which promptly imposed a five per cent cut-off for oil exports to the Philippines. In 1980, the OIC declared its support for the struggle of the “Bangsa Moro” people for “self-determination”, thus for the first time referring to the Moro people as a nation and entertaining options other than regional autonomy. Clearly, the message was that if the Philippine government did not abide by the Tripoli Agreement, the OIC could shift to endorsing the MNLF's original secession bid. Furthermore, the OIC urged member countries "to assert economic, social and political pressure on the government of the Philippines to induce it to implement the Tripoli 
Agreement”. ${ }^{\text {xvi }}$ In response, Saudi Arabia ended a contract for the delivery of 10,000 barrels of oil per day in November 1980.

Time and again, Misuari tried to get the OIC’s avowed support for Bangsa Moro self-determination transformed into outright support for secession, but failed each time. In what became a yearly ritual, the OIC passed resolutions calling on the Philippine government to implement the Tripoli Agreement or to speed up its implementation, but not going much farther. In January 1986, the OIC reiterated its support for the "Bangsamoro struggle for self-determination” and called on member countries to extend all forms of material and financial assistance to the MNLF in its capacity as "the sole legitimate representative of the Bangsamoro people”. xvii The following month, the Marcos regime was toppled by a popular uprising.

\section{Post-Marcos Era: De-internationalization Fails}

With the assumption of Corazon Aquino of the presidency, prospects for a negotiated settlement to the long-standing Mindanao conflict looked promising. The new president and her murdered husband, Senator Benigno Aquino, had been sympathetic to the Moro struggle. The MNLF had openly campaigned for Mrs. Aquino. Soon after her victory, all three Moro rebel forces expressed willingness to talk peace.

In September 1986, Aquino, breaking protocol, met with Misuari, who had just come back to the Philippines, in his home province, Sulu, to talk peace. GRP-MNLF talks reopened. In January 1987, the two sides signed the Jeddah Accord in Jeddah, Saudi Arabia, agreeing to hold further discussions on a "proposal for the grant of full autonomy to Mindanao, Basilan, Sulu, Tawi-Tawi and Palawan”. The two sides also agreed on a ceasefire. The efforts at conflict resolution, however, quickly reverted to a power-and-rights contest, albeit not with as much bloodshed as before. 
A constitutional commission formed by Aquino came up with a draft of a new Philippine charter which provided for the creation of an autonomous region in "Muslim Mindanao" through an organic act to be passed by Congress and subject to a plebiscite in the proposed region. ${ }^{\text {xviii }}$ Fearing that the Aquino government, like its predecessor, would reduce the area of autonomy stipulated in the Tripoli Agreement, the MNLF asked Aquino to suspend the autonomy provisions. Aquino, however, turned down the request. The new charter was ratified in February 1987.

Having adopted a policy to de-internationalize the Mindanao conflict early on, the Aquino government sought to avoid further OIC mediation and reference to the Tripoli Agreement in dealing with the MNLF. ${ }^{\text {xix }}$ Thus, when formal talks to discuss autonomy got underway immediately after the new charter's ratification, these no longer involved OIC participation.

In pursuance of its “rights” under the Tripoli Agreement, the MNLF demanded the outright creation by presidential order of an autonomous region consisting of the thirteen provinces stated in the agreement. The government, however, insisted on sticking with the autonomy provisions in the new constitution. In an attempt to break the impasse, Aquino's emissaries offered Misuari the government's “long-term” commitment to grant autonomy to eight provinces - and even upped this later to ten. ${ }^{\mathrm{xx}}$ Misuari refused to give in. The talks broke down. The Aquino administration pressed ahead with its autonomy plan, creating a Regional Consultative Commission to assist it in the enactment by Congress of the organic act on autonomy. Meanwhile, Aquino succeeded in luring one of Misuari’s main rivals, Pundato, whom she appointed head of the Office for Muslim Affairs.

The OIC took on an increasingly critical stance, appraising the government's moves as being in no way in conformity with the Tripoli Agreement, reminding it that the agreement was a binding international accord, and reiterating its support for the MNLF as the sole 
representative of the Bangsamoro people. Emboldened, the MNLF campaigned for full membership in the OIC, eventually submitting a formal application. The Moro rebels aspired to follow in the footsteps of the Palestine Liberation Organization, which had been accepted as a full member of the OIC even though it was not - or at least not yet - a sovereign state. By threatening to adopt "measures” if the government did not implement the Tripoli Agreement, the OIC hinted at approving MNLF's application. ${ }^{\mathrm{xxi}}$

De-internationalization had backfired. Scrambling to prevent the MNLF from gaining full membership, the government was forced to go back to the international arena and to wage a diplomatic counter-offensive. Aquino’s emissaries explained how the autonomous region being set up in "Muslim Mindanao" was in keeping with the letter and spirit of the Tripoli Agreement. Exploiting the split in Moro movement's ranks, they stressed that the government was willing and prepared to talk peace but only with a unified Moro panel consisting of representatives of the three Moro rebel groups. The government's efforts worked. The OIC “deferred” the issue of the MNLF's membership.

In August 1989, Aquino signed the law creating the Autonomous Region of Muslim Mindanao (ARMM). In a plebiscite three months later - boycotted by the MNLF and the MILF - only four provinces voted to be part of the ARMM. After the first elections for the new region, the ARMM was inaugurated in November 1990. All through this time, the government made sure to keep the OIC member countries abreast with its efforts to implement autonomy ostensibly in fulfillment of its commitments in the Tripoli Agreement.

In 1991, the OIC acknowledged the government's efforts to bring peace in Mindanao, producing what then Defense Secretary Fidel Ramos described as "the mildest resolution ever passed by the OIC on the issue". ${ }^{x x i i}$

\section{6: The “Final Agreement"}


A few weeks before the start of the 1992 electoral campaign, Ramos, the Aquino-backed presidential candidate, secretly met with Khadaffy in Tripoli to discuss a comprehensive solution to the Mindanao conflict. At that particular time, the MNLF was very much weakened militarily and politically and had dipped to virtually its lowest point. Apart from the split in its ranks, five years of ceasefire with the Aquino government, though broken intermittently, had somewhat devitalized the MNLF fighters. In the international front, the government had succeeded in frustrating the MNLF's OIC membership bid and in neutralizing its diplomatic initiatives in general. The OIC itself was preoccupied with more pressing concerns affecting Muslim communities in other parts of globe. Despite the MNLF's weakened position, however, Ramos recognized that the MNLF still commanded a large guerrilla force and continuing support from the OIC, and that the long-unresolved conflict in Mindanao would constitute a major stumbling block to the country's efforts to achieve NIC (newly-industrialized country) status.

Within a few months after winning the elections and assuming the presidency, Ramos reopened talks with the MNLF. The OIC returned in the broker's role. Unlike the Aquino administration which had resisted giving the OIC a role in GRP-MNLF talks, the Ramos administration welcomed OIC participation, looking favorably at how the organization had never actually endorsed the MNLF's secession bid and had pressured the Moro rebels time and again to accept regional autonomy.

Once again, the negotiations employed a power-based approach, involving the usual "hard bargaining”, with a modicum of the “rights” element. This time, however, there was a more substantial effort on the part of the government to hear out and accommodate the MNLF's interests. With the cards stacked heavily in its favor, the government could afford to be magnanimous, to give as many economic and political concessions as the 1987 constitution would allow. Government policy revolved around accommodation and cooptation - 
specifically, how to accommodate the MNLF forces in government and coopt them "with grace” xxiii Providing employment for ex-guerrillas and their kin through their integration into the Philippine armed forces and police was a good example of the accommodation of the MNLF's interests.

The peace agreement signed by the government and the MNLF in September 1996 was billed as the "final agreement on the implementation of the 1976 Tripoli Agreement". It provided for the establishment of a new regional autonomous government. In spelling out the workings of autonomy, the 1996 agreement basically followed and merely elaborated on the provisions of the 1976 agreement regarding the administrative system, executive and legislative bodies, the special regional security forces, etc.

Before the setting up of the new autonomous region, the people in fourteen provinces and nine cities - the very same area supposed to be covered by the autonomous region under the Tripoli Agreement ${ }^{\text {xxiv }}$ - would vote in a plebiscite whether they would want to be part of the region. The key difference of this plebiscite-then-autonomy arrangement from previous ones (1977 and 1989) was that it would be preceded by a three-year transitional period in which the MNLF would be given the chance to run transitional structures of autonomy, prove itself in governance and thus improve the chances of convincing the people in most if not all of the fourteen provinces and nine cities to vote in favor of autonomy. Also during this period, MNLF elements would be integrated into the Philippine armed forces and police.

Two new governmental bodies, the Southern Philippines Council for Peace and Development (SPCPD) and the Consultative Assembly, would be created to accommodate - or coopt - MNLF members into the government. During the transitional period, the SPCPD, in consultation with the Assembly, would promote and coordinate "intensive peace and development efforts" in the fourteen provinces, which would be designated as a Special Zone of Peace and Development in Southern Philippines (SZOPAD). Much of the furor surrounding 
the 1996 agreement focused on the functions and powers of the SPCPD, but it was another vehicle of accommodation and cooptation - the existing ARMM - that was actually much more powerful, having direct administrative functions and more funds. Though not stipulated in the text of the official agreement, the turnover of effective control over the ARMM was part of the GRP-MNLF “deal”.

After the signing of the 1996 accord, Ramos appointed Misuari SPCPD chairman and ensured that he would become ARMM governor. To comply with constitutional processes regarding ARMM, Ramos’ ruling coalition and the MNLF fielded a joint ticket in the 1996 ARMM elections with Misuari at the helm. The lone candidate for governorship, Misuari won hands down.

\section{Conflict Unresolved}

Ostensibly, the quarter-of-a-century power contest between the government and the MNLF had come to an end. The MNLF had started out during the Marcos period struggling for an independent Bangsamoro state covering the whole of Mindanao; settled for an autonomous region of thirteen provinces under the Tripoli Agreement; reverted to its original position when Marcos insisted on a plebiscite; rejected Aquino's offer of an autonomous region of up to ten provinces; and ended up accepting Ramos' offer of an autonomous region of still undetermined area. The MNLF had come down a long way. Nothing to wonder about, especially if one took note that the level of GRP-MNLF armed clashes had continuously declined since 1975.

What is perhaps more of a wonder is how the MNLF managed to keep up the power contest with the government through all that time. Thanks mainly to successes in the politico-diplomatic front, the MNLF more than made up for its setbacks in the battlefront and managed to stay in the power game. The key card that the MNLF played in the politico-diplomatic struggle was none other than the OIC. "Without the OIC, the MNLF 
struggle would not have been as meaningful and Misuari only knew this too well,” noted Samuel K. Tan. “Without the OIC’s consistent support for the MNLF, the Moro struggle would have gone the way of all its frustrated struggles in the past. The position and status of the MNLF in the OIC has remained the most important leverage of the Moro struggle.

Psychologically, the OIC has given moral and political strength that military forces could not.”xxv

As the "final agreement" on the "full implementation" of the 1976 Tripoli Agreement, the 1996 peace agreement was supposed to mark the resolution of the GRP-MNLF armed conflict, to provide the impetus for resolving the government's conflict with other Moro rebel groups and eventually to pave the way for a just and lasting peace in Mindanao. Since the signing of the accord, the armed hostilities between government and MNLF forces have indeed stopped. But the armed conflict between the government and other Moro rebel groups has continued, and the GRP-MNLF conflict itself has recently shown signs of not really being resolved.

Even before the recent escalation of the war between the government and the MILF and between the government and the Abu Sayyaf, Jacques Bertrand already described the 1996 peace agreement as “fragile”. He cited several reasons why it might be failing:

First, the transitional structures of autonomy have failed to provide a good test for future autonomous institutions because of mismanagement and corruption. Nur Misuari and the MNLF leadership failed to show that their control of autonomous institutions could benefit all Muslims and non-Muslims in a new autonomous region. Second, and partly as a result of the first reason, these structures received little support from groups other than the MNLF because of the mainly Tausug base of the MNLF and the failure to involve non-Muslims of Mindanao in the peace negotiations. As a result, the current autonomy proposal is not perceived to be an 
adequate solution for all groups, including non-Tausug Muslims supporting the rival Moro Islamic Liberation Front (MILF). Third, the agreement did not address the issue of land rights, which is crucial to any long-term peace in Mindanao. Fourth, the peace accord has not produced many of its expected benefits. Most significantly, it has not yet led to an improvement in the living standards of Muslims. While MNLF leaders can be blamed in part, a lack of strong commitment and resources from the Philippine government is also responsible. ${ }^{\text {xxvi }}$

Underscoring the failure of the 1996 agreement to resolve the long-standing armed conflict in Mindanao is the government's launching of an "all-out war” against the MILF and the Abu Sayyaf. Now, even the GRP-MNLF conflict appears to be still very much around. In a meeting of OIC senior officials in Jeddah in late May, Misuari accused the Philippine government of "dilly-dallying” on autonomy and not living up to its commitments under the 1976 and 1996 agreements. He practically revived the MNLF’s campaign for secession, warning that if the MNLF did not get genuine autonomy, it would have no option left but to fall back to "the Bangsamoro people's fundamental and inalienable right to self-determination and independence”. Once again, he asked the OIC to elevate the MNLF from an observer to a full member.

The power contest between the government and the MNLF continues. Once again, Misuari is wielding the OIC card. It is not inconceivable that the MNLF, to strengthen its hand in the power game, could go back to the battlefront.

\section{The Weaknesses of a Power-based Approach}

The GRP-MNLF experience is illustrative of the weaknesses of a power-based approach to conflict resolution. Of the three approaches to conflict resolution, the power-based 
approach is deemed to be the least cost-effective, i.e. the most costly as well as the least effective. Peck writes:

Power contests tend to be the most costly of the three. Typically they consume more time, energy and money than other approaches and when they escalate, they often lead to enormous destruction of resources (through deaths, injury, property or infrastructural damage) as well as lost opportunities (for trade, etc.) ...

Satisfaction with outcome is another important factor, since it has consequences for the recurrence of the conflict. When the parties are satisfied with the outcome, future conflict is less likely. When they are dissatisfied, it is more likely. Not surprisingly, in a power contest, the losing party is usually dissatisfied with the outcome. Thus, this approach, even when it appears to have settled a situation, may do so only temporarily. Unaddressed grievances and dissatisfaction can make the resolution unstable and result in a recurrence of the conflict once the losing side has regained sufficient strength to renew the struggle. ${ }^{\text {xxvii }}$

The protracted power contest between the government and the MNLF has exacted a very heavy toll in human suffering and in material costs. Over 120,000 people have been killed, tens of thousands have been injured and more than a million have lost their homes and farmlands. Property and goods worth billions of pesos have been destroyed and the contending parties have spent billions more to wage war in both the military and the politico-diplomatic fronts. ${ }^{\text {xxviii }}$ Inspite of all the human and material costs, the GRP-MNLF power contest still has not resulted in a real resolution of the strife in Mindanao.

Like the 1976 Tripoli Agreement and the 1987 Jeddah Accord, the 1996 peace agreement did try to address the grievances of the Moro people, such as the lack of self-rule and the lack of economic development. But after nearly four years - and still in the transition phase - the 
MNLF has not been satisfied with the outcome. The dissatisfaction has stemmed not so much from the "dilly-dallying" of the government on autonomy. The MNLF is worried that with the meager tangible results from the "intensive development efforts" set in the transitory phase, enthusiasm for a new autonomous region has waned and the possibility of attaining an area of autonomy larger than the present ARMM has become very unlikely. The MNLF has put the blame for all the failings in implementation squarely on the government without acknowledging its own shortcomings. Given the dismal implementation of the 1996 agreement, the MILF and the Abu Sayyaf, which had rejected the accord from the outset, now all the more assertively contend that the Moro people can attain genuine self-rule and development only through secession.

Several major grievances were not addressed by the 1996 accord. As Bertrand has pointed out, the accord left out the question of land ownership, particularly "the problem of private land ownership and the decades of displacement of Muslims from their lands”. xxix For Islamic movements like the MILF and the Abu Sayyaf, the 1996 agreement, signed by “secularists” (the Philippine government and the MNLF), did not adequately tackle what to them is of utmost significance - the disregard for the Moro people’s Islamic identity and way of life - a problem that in their conviction can only be fully solved through the establishment of an independent Islamic state. Perhaps still another unaddressed grievance of the other Moro rebel groups, which may even have been reinforced by the 1996 agreement, is what is perceived to be the government's practice of trying to divide and rule the Moros, favoring and forging a deal with one Moro rebel force dominated by a certain ethnic group and excluding the others, instead of adopting a more evenhanded or comprehensive approach.

The GRP-MNLF experience is also illustrative of the limitations of a rights-based method, the secondary approach employed to try to resolve the Mindanao conflict. Early on, the government and the MNLF could not agree on the interpretation and the method of 
implementation of a common standard they had set in 1976 - the Tripoli Agreement. Thus, quite easily, the disagreements led back to a power-based approach.

\section{GRP-MILF Conflict Resolution: Another Power Contest}

As in the GRP-MNLF conflict, the government and the MILF have been employing a power-based approach in the resolution of their conflict - a power contest fought out both in the battlefield and in the politico-diplomatic arena. With the MILF constantly making references to the Tripoli Agreement until the early 1990s, the GRP-MILF power contest has been tinged with a "rights" element too. The two sides have conducted peace negotiations to try to resolve their armed conflict, but, as in the GRP-MNLF case, these have just been a continuation of the power struggle by other means. The GRP-MILF contest in the diplomatic front is now part of what has just shaped up into a three-cornered diplomatic contest involving the Philippine government, the MNLF and the MILF. ${ }^{\mathrm{xx}}$

Early on, in 1979, the government entered into negotiations with Salamat's group (then still called the "new MNLF”). It was obvious, however, that the Marcos regime was not really serious in working for a comprehensive political settlement of the conflict in Mindanao but just maneuvering to take advantage of the split in the MNLF ranks. Still weak militarily and politically (with the OIC continuing to recognize Misuari as MNLF chairman), Salamat's group did not get anywhere in its talks with the Marcos government.

While trying to build up its armed strength, Salamat's group attempted to break ground in the diplomatic field too. Towards the OIC, Salamat took a moderate, conciliatory stance, calling for the implementation of the Tripoli Agreement, in contrast to the more "radical" Misuari who had reverted to the secessionist position. The tactic did not work. Salamat's group suffered a grave political setback in early 1980 when the chairman of the Kutawato Revolutionary Committee, Amelil Malaguiok, together with several field commanders, 
defected to the government. This adversely affected not just the group’s military capabilities but its diplomatic initiatives as well. The OIC tried to reconcile Misuari and Salamat, and later, to get the three MNLF factions to negotiate with the government as a "united front” but all its efforts failed. In 1984, Salamat's group changed its name to MILF to distinguish itself from Misuari’s group and to emphasize its Islamic character.

Soon after the fall of Marcos, the MILF organized a three-day rally in Cotabato City calling for GRP-MILF peace talks and for the implementation of the Tripoli Agreement. Participated in by close to 100,000 people, it was Cotabato City’s biggest rally ever. Despite this show of strength, the MILF still had difficulty in drawing the government's attention. Efforts of the OIC and the Muslim World League to get the MNLF factions (Misuari and Pundato) and the MILF to form a common negotiating panel fell through. In the absence of such a common panel, the Aquino government opted to negotiate with the MNLF (Misuari), hoping to deal with the other Moro rebel groups later. Protesting their exclusion from the talks, the MILF staged a five-day military offensive in January 1987. To assuage the MILF, Aquino met briefly with MILF leaders Al Haj Murad (vice chairman for military affairs) and Iqbal in Cotabato City.

As the government became preoccupied with its talks with the MNLF (which soon broke down), and later with the establishment of the ARMM despite MNLF and MILF objections, GRP-MILF talks never got underway during the Aquino term. In the meantime, the MILF steadily built up its military forces and weaponry, and expanded and transformed its military training camp, Camp Abubakar, into a sprawling permanent encampment with a thriving Islamic community that the government forces reportedly could no longer easily attack - a virtual stronghold. In December 1990, an MILF delegation managed to get invited to the OIC summit meeting in Dakar, Senegal. The OIC passed a resolution urging the Philippine government to resume negotiations with the MNLF and the MILF, mentioning the MILF for 
the first time. ${ }^{\text {xxxi }}$ For a long while after that, however, nothing more was mentioned about the MILF in OIC resolutions.

\section{The MILF Outmaneuvers the Government at the Talks}

The Ramos government started peace talks with the MILF nearly four years after opening talks with the MNLF and just two years before the end of its term. By then, the MILF had already shifted to a secessionist position, maintaining that an Islamic state was one of the prerequisites in the perfection of a Muslim's service to Allah and the only way Moros could attain prosperity "in this world and in the hereafter". xxxii This was in sharp contrast to the position of the MNLF, which had already accepted the government's offer of regional autonomy. The MILF’s secessionist position, however, differed from the MNLF's original stance in that the Moro state would cover not the whole of Mindanao but only areas that would vote for separation in a plebiscite.

Because of their power-based approach to conflict resolution, it had taken the government and the MILF nearly two decades of power contest before they finally sat down to engage in serious peace negotiations. The MILF could not duplicate what the MNLF had achieved - mustering in only a few years enough clout in the military and politico-diplomatic arenas to force the government to come to the negotiating table for serious talks. And the MILF could not get the government to agree to the participation of a prestigious entity like the OIC as broker in the talks or to hold the talks outside the Philippines - as either of these could have been interpreted as the 'internationalization” of the conflict. But when the MILF did enter into peace talks, it was at a time when the MNLF's star was already fading and the MILF's fast rising.

As the government refused to discuss the MILF's demand for secession and insisted that the talks stick within the framework of the Philippine constitution, the MILF tried an indirect 
approach to bring the discussion to its main demand. For the substantive part of the peace talks, the MILF proposed a single talking point - “To solve the Bangsamoro problem” - and expressed the hope that the peace talks would find "a political and lasting solution to this [Bangsamoro] problem ... with the end in view of establishing a system of life and governance suitable and acceptable to the Bangsamoro people.” When the government side said that the MILF's “talking point” was too general and too vague, the MILF clarified that its talking point involved the following issues: ancestral domain; displaced and landless Bangsamoro; destruction of properties and war victims; human rights issues; social and cultural discrimination; corruption of the mind and the moral fiber; economic inequities and widespread poverty; exploitation of natural resources; and agrarian related issues. The GRP-MILF talks did not get beyond the exploratory stage during Ramos' term, but the two sides did conclude the July 1997 ceasefire agreement.

In August 1998, just a few weeks after its inauguration, the Estrada government signed an "agreement of intent" with the MILF in which the two sides committed themselves to pursue talks on the substantive issues of the Mindanao conflict as soon as possible. The start of the substantive talks kept being postponed, however, as the two sides reached an impasse over the issue of the recognition and delineation of "MILF camps or positions".

The MILF had demanded, ostensibly for ceasefire purposes, that the government recognize its 46 camps - 13 main camps and 33 auxiliary camps - and that no government troops be allowed inside these camps. The MILF argued that recognition of its areas would help prevent armed clashes between government and rebel forces. As part of its “confidence-building measures”, the government “acknowledged” Camp Abubakar and six other MILF camps. The two sides could not agree, however, on the precise area and the delineation of the boundaries of the seven camps. The way the government saw it, each of the seven acknowledged MILF camps consisted of only several square kilometers. The MILF, 
however, maintained that the camps covered a much wider area. Camp Abubakar, for instance, was said to have an area of 1,198 square kilometers - the size of a small province.

Although the area and delineation of the MILF camps were never settled, the government's acknowledgement of the camps in itself constituted a political coup for the MILF. It was tantamount to a de facto recognition of MILF territory - a feat that neither the MNLF nor the National Democratic Front ever achieved in their negotiations with the government. ${ }^{\text {xxxiii }}$ Clearly, the MILF had outsmarted the government in the negotiating game.

\section{All-out War and a Three-Cornered Diplomatic Struggle}

The "verification" and "acknowledgement" of the MILF camps, which were supposed to have been finished within the exploratory phase of the talks, dragged on. With this issue still unresolved, the two sides decided to proceed with the substantive talks in October 1999. The talks got nowhere. In the course of conducting further "verifications", the government side realized that its recognition of the MILF camps was a blunder and that it had been outmaneuvered.

To correct its mistake in acknowledging the MILF camps, the government decided to simply obliterate them militarily. In February 2000, government troops started attacking the MILF camps, using various pretexts to justify the attacks. When the MILF retaliated by attacking AFP garrisons and occupying a town in Lanao del Norte for ten days in March, Estrada declared an "all-out war" against the rebels. A series of kidnappings, hostage-taking and grisly executions perpetrated by the Abu Sayyaf in Basilan, Sulu and a nearby Malaysian island provided some hardliners with the opportunity to stir up anti-Muslim sentiments and to whip up anger and hatred against Moro rebels in general. Government forces overran the MILF camps one after another, hoisting the Philippine flag at each captured site. The MILF's vaunted 
stronghold, Camp Abubakar, fell in early July; its defenders proved powerless against the bombings and air attacks of the Philippine armed forces.

The MILF suffered major setbacks in the battlefield, but opportunities opened up in the politico-diplomatic field. The escalation of armed hostilities in Mindanao could not but draw the attention and concern of the OIC, which had been closely monitoring the implementation of the 1996 peace agreement. By unleashing an “all-out war”, the government had risked bringing about something it had wanted to avoid: the "internationalization” of the GRP-MILF conflict. The MILF went on a diplomatic offensive. Almost completely boxed out by the MNLF in the OIC in the past, the MILF now hoped to score points in its bid to gain recognition from the international organization as $a$ or even the representative of the Bangsamoro people and eventual entry into, the international organization - even at the expense of the MNLF. At the OIC conference in Kuala Lumpur in June, a three-way diplomatic tussle ensued, involving the Philippine government, the MNLF and the MILF.

The OIC adopted a resolution drafted by the MNLF, but the government succeeded in having a crucial paragraph on the armed conflict in Mindanao amended in such a way that it would not appear to be the aggressor. The draft resolution contained the following: "[The OIC] urges the Government of the Republic of the Philippines to immediately halt its military offensive against the Moro Islamic Liberation Front (MILF) and the Bangsamoro people and reach a peaceful solution to the existing problem in Mindanao.” This was revised to: “[The OIC] urges the government and the Moro Islamic Liberation Front to immediately halt their existing hostilities and reach a peaceful solution to the current problem in Mindanao.”xxxiv In the MNLF's view, the government “jumped from the frying pan into the fire” when it had the draft amended. According to Misuari, the amended version placed the MILF on the same level as the Philippine government, “a de facto state of belligerency”. ${ }^{x x x}$ 
It would seem that the MNLF emerged the "winner” at Kuala Lumpur. The draft resolution it had prepared was the for the most part carried. Although it did not get promoted to OIC full membership, it retained observership and its status as "the sole legitimate representative of the Bangsamoro people”. Apart from being assured of increased economic assistance from OIC countries for reconstruction and rehabilitation in Mindanao, the MNLF also got the OIC's support for the extension of the transitory phase of the 1996 agreement and the postponement of ARMM elections.

But Kuala Lumpur was just one round, one battle. In the struggle for OIC recognition, the MILF has one distinct advantage over the MNLF: it has active guerrilla forces on the ground. If the MILF keeps up with or intensifies its guerrilla war in Mindanao, the OIC would have no choice but to put more pressure on the government to reopen negotiations. At the same time, it would become increasingly difficult for the OIC to keep the MILF at arm’s length and continue to recognize the MNLF as the sole, legitimate representative of the Moro people.

\section{Again, the Pitfalls of a Power-based Approach}

The GRP-MILF experience bears out once again the pitfalls of a power-based approach (with a rights-based element) to conflict resolution. To get itself heard and be treated as a force to be reckoned with, the MILF had to wage a protracted armed struggle against the government, a conflict that contributed to the heavy toll in human suffering and in material costs earlier cited. The MILF also tried its hand in the politico-diplomatic arena, but was largely boxed out by the MNLF. After two decades of struggle, primarily because of the armed strength it had accumulated, the MILF managed to compel the government to negotiate with it seriously. At the negotiating table, however, the MILF probably overplayed its hand when it pushed the government to “acknowledge” its territory (aka camps). Declaring an “all-out war”, the government attacked and destroyed the MILF camps and delivered a big blow on the rebels. By 
doing so, however, the government allowed the MILF to take the initiative in the diplomatic front. Thus far, that is how the GRP-MILF power contest has played out. It has been long and costly, yet the resolution of the conflict is nowhere in sight.

Worse could be ahead. Now that the government has overrun and dismantled the MILF camps so quickly, it will probably be even more determined to press ahead with its "all-out war” to crush the Moro rebels. On the other hand, now that the prospects in the politico-diplomatic arena look promising, the MILF will likely be even more determined to carry out guerrilla offensives. With conditions in Mindanao continuing to deteriorate, the MNLF may very well intensify its campaign for OIC full membership status. And now that its kidnapping and hostage-taking have grabbed so much international attention and proven very lucrative, the Abu Sayyaf may very well continue with its kidnapping ways. The government may be able to defeat the MILF or the Abu Sayyaf militarily, but this would be a hollow victory. It would most likely only drive uncaptured rebels to join the undefeated rebel group - or to start a new one.

Almost three decades of a traditional, power-based approach in conflict resolution combined with a right-based method has not brought about a stable and lasting peace in Mindanao. Why is it that the contending parties (the government and the Moro rebels) as well as the third party mediator (the OIC) have stuck it out for so long with such an approach and not shifted to the alternative - an interest-based approach?

Unawareness or unfamiliarity, probably. “This ‘alternative’ dispute resolution approach," clarifies Peck, "has only risen to prominence in recent years, following the more intensive study of its theoretical basis and the steps involved in its implementation. ${ }^{\mathrm{xxxvi}}$ Regrettably, she adds, many decision-makers are unaware that such an approach exists. ${ }^{\text {xxxvii }}$

\section{Shift to an Interest-based Approach?}


With the obvious failure of a power-and-rights-based approach to resolving the long-drawn conflict in Mindanao, it is perhaps time to consider a different tack - an interest-based approach. Peck elaborates on this alternative approach:

In a problem solving approach [through interest-based negotiation], the focus of negotiation and the starting point for generating possible solutions are the party's interests. Interests represent the real motivation of the parties - the needs, wants, fears and concerns of each side which lie behind their positions ... Interests, may, however, have multiple layers, with both more superficial interests or aspirations as well as deeper concerns representing basic human needs which are common to all. Numerous human needs have been studied, including the need for physiological maintenance (food, shelter, etc.); the need for safety and security; the need for self-esteem, self-respect and dignity; the need for autonomy and control; the need for affiliation and belongingness; the need for social identity and recognition; the need for participation; the need for meaning and so on (Burton, 1990). Typically, however, it is the deeper interests which account for the passions that drive intractable conflicts. Individuals are often unwilling to yield on these issues and may even be willing to die for them. Thus, it is these deeper interests which must be understood and addressed if conflict prevention or resolution is to be effective. Engaging in such an approach requires each side to consider: "Why is the other party advocating a given position?” "What are the fears and concerns that are behind their claims or demands?" "What do they consider to be their basic human needs that are being denied, frustrated or threatened?” Such an analysis requires the parties to try to understand the historical and cultural perspective of the other side in order to better comprehend why it feels aggrieved. 
In the process of exploring interests, parties are compelled to develop a more accurate understanding of each other's motivations which also helps to break down misperceptions ...

Once interests are understood, the negotiation process can move on to open up possibilities for an innovative solution by inventing options based on each side’s concerns which could meet the parties' various interests. Once new options have been generated, the promising ones can be pieced together in an attempt to build a solution which is satisfactory to both parties. These can then be gradually refined to further address each sides's major interests until the solution meets enough of each party’s basic interests that each is willing to agree. ${ }^{\text {xxviii }}$

Peck explains the advantages of an interest-based approach:

[A]n interest-based approach tends to be the most cost-effective. Since it attempts to address and meet the parties' underlying interests and to achieve a satisfactory outcome for all concerned, it is unlikely to lead to the destruction of resources. Because the goal is to meet all parties' interest, disputants are more likely to be satisfied with the outcome. Use of such a problem solving approach thus minimizes damage to the long-term relationship. Since the parties' concerns will have been addressed, the conflict is less likely to recur and the resolution will be more stable. ${ }^{\mathrm{xxxix}}$

In the Mindanao conflict resolution process, government and rebel negotiators had known of some or even many of the other side’s interests, but these were not systematically explored. Negotiations had tended to focus on the parties' positions - secession, thirteen- or fourteen-province autonomy, etc. - and these had defined the entire peace process. During the Ramos period and the early Estrada period, some government negotiators tried out interest-based "problem solving” methods, but these were still pursued within an overall 
power-based framework and were eventually reversed by more hawkish elements in the Estrada government.

All parties concerned in the Mindanao conflict have to be part of an interest-based conflict resolution process - not just the government, the MNLF and the MILF, but also opposition parties, Christian or “majority-Filipino” organizations, other Muslim or Moro organizations, and associations of the non-Muslim indigenous peoples of Mindanao known collectively as lumads. (The Abu Sayyaf could be part of the process if it puts a stop to kidnappings and hostage-taking and abides by international humanitarian law.) Bertrand points out that Christians and lumads were largely opposed to the 1996 agreement from the outset as they feared inclusion in a region ruled by Muslims. "If non-Muslims had been included more fully in the negotiations," he writes, "they might have been more supportive of the process, but they were not." $x \mathrm{l}$

The interests of the parties concerned have to be more conscientiously and methodically explored and addressed. Several major Moro grievances have already been mentioned earlier - lack of genuine self-rule, economic backwardness, displacement from lands, disregard for Islamic identity and way of life, etc. But what really are the foremost interests, the deepest needs, wants, fears and concerns of each of the Moro rebel groups? What exactly are the government's interests - national sovereignty, territorial integrity, security, national pride? And what about those of the Christians and lumads - why would they fear being part of a region or state run by Muslims? What options can be drawn up that could meet all the parties’ various interests?

As the outside entity that has commanded and still commands the respect of all the parties concerned in the Mindanao conflict, the OIC may be able to play a much better role in mediation if it too adopts less of a traditional, power-based approach and more of an interest-based one. Critical resolutions, recognition as "legitimate representative”, 
observership, full membership, belligerency status, etc. - the power contest in the politico-diplomatic arena could stretch on and on without bringing about a real resolution of the armed conflict. Perhaps the OIC could put its influence and power to better use by getting the contending sides to explore and address each other's interests, needs, wants and fears, and to work together to find a creative solution to the seemingly intractable conflict.

\footnotetext{
${ }^{\text {i }}$ Philippine Daily Inquirer, July 11, 2000.

ii Philippine Daily Inquirer, July 19, 2000.

iii Connie Peck, The United Nations as a Dispute Settlement System, The Hague: Kluwer Law International, 1996, pp. 10-11.

iv Ibid., pp. 41-42.

v The areas covered by the MNLF's call for secession actually included the islands and island groups of Mindanao, Basilan, Sulu, Tawi-Tawi and Palawan.

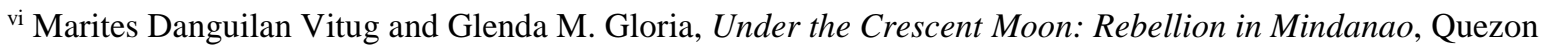
City: Ateneo Center for Social Policy and Public Affairs and Institute for Popular Democracy, p. 60.

vii In a manifesto dated April 28, 1974, the MNLF declared the severance of all ties with "Filipino colonialism” and the establishment of the "Bangsamoro Republik” (Moro National Liberation Front, "Manifesto on the Establishment of the Bangsamoro Republik” in Cesar Adib Majul, The Contemporary Muslim Movement in the Philippines, Berkeley: Mizan Press, 1985, pp. 117-119). Bangsa means “nation”.

viii Organization of the Islamic Conference (OIC), $3^{\text {rd }}$ Islamic Foreign Ministers' Conference (ICFM), Jeddah, Saudi Arabia, February-March 1972.

ix OIC, $5^{\text {th }}$ ICFM, Kuala Lumpur, Malaysia, June 1974.

${ }^{\mathrm{x}}$ Ibid.

xi Peck, p. 41.

xii Mara Stankovitch (ed.), “Compromising on Autonomy: Mindanao in Transition”, Accord, Issue 6/1999, p. 77.

xiii Vitug and Gloria, p. 31
} 
${ }^{\text {xiv }}$ Paragraph 16 of the Tripoli Agreement.

${ }^{x v}$ OIC, $8^{\text {th }}$ ICFM, Tripoli, Libya, May 1977.

${ }^{\text {xvi }}$ OIC, $11^{\text {th }}$ ICFM, Islamabad, Pakistan, May 1980.

xvii Vitug and Gloria, p. 36.

xviii 1987 Philippine Constitution, Article X, Sections 15-21.

xix Soliman M. Santos, Jr., “The Philippines-Muslims Dispute: International Aspects from Origins to Resolution” (unpublished manuscript), p. 19.

xx Vitug and Gloria, p. 39.

xxi Ibid., p. 66.

xxii Ibid., p. 67.

xxiii Ibid., p. 43

xxiv One of the original thirteen provinces, South Cotabato, was divided into two provinces.

${ }^{x x v}$ Samuel K. Tan, The Internationalization of the Bangsa Moro Struggle, Quezon City: University of the Philippines Press, 1993

xxvi Jacques Bertrand, "Peace and Conflict in the Southern Philippines: Why the 1996 Peace Agreement is Fragile”, Pacific Affairs, Spring 2000, p. 37.

xxvii Peck, p. p. 11.

xxviii The figures cited here cover the damage wrought by the war between the government and the Moro rebels in general and not just the GRP-MNLF conflict.

xxix Bertrand, pp. 51-52

xxx Nathan Gilbert Quimpo, “Three-cornered Diplomatic Battle in Kuala Lumpur”, Philippine Daily Inquirer, June 25, 2000.

xxxi OIC, 6 ${ }^{\text {th }}$ Islamic Summit, Dakar, Senegal, December 1990.

xxxii Abhoud Syed Mansur Lingga, “The Political Thought of Salamat Hashim” (masteral thesis), pp. 37-39

xxxiii Nathan Gilbert Quimpo, “The Thorny Issue of the MILF Camps” (Part 2), Philippine Daily Inquirer, June 2, 2000.

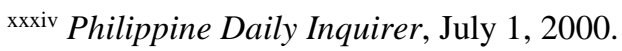

xxxv Ibid.

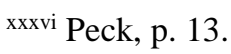

xxxvii Ibid., p. 38. 
xxxviii Ibid., pp. 38-40.

xxxix Ibid., p. 12.

${ }^{x l}$ Bertrand, p. 52. 